\title{
The Variations of Words in Their Meanings
}

\author{
Firangiz Furman Kurbanova ${ }^{1}$ \\ ${ }^{1}$ Azerbaijan University of Languages, Azerbaijan \\ Correspondence: Firangiz Furman Kurbanova, Azerbaijan University of Languages, Azerbaijan. E-mail: \\ ffkurbanova@yahoo.com
}

$\begin{aligned} & \text { Received: November 17, } 2015 \\ & \text { Accepted: December 10, } 2015 \quad \text { Online Published: March 28, } 2016 \\ & \text { doi:10.5539/ijel.v6n2p139 }\end{aligned}$ URL: http://dx.doi.org/10.5539/ijel.v6n2p139

\begin{abstract}
The article investigates the variation of full word-forms and empty word-forms in the English language. Having investigated a lot of linguistic sources the author gives the explanation to them. Firstly, the author investigates the meanings of words. She considers words to be ambiguous notions both in everyday speech and in linguistics. As linguists claim words may be considered as forms whether spoken or written, or as composite expressions which have form and meaning. Then basing on linguistic sources the author gives the classes of word-forms in English: full forms and empty forms. The author investigates the differences between the two classes. She states that empty word-forms differ grammatically and semantically from full-words.
\end{abstract}

Keywords: word, meaning, lexeme, full, empty, form, semantic, speech, grammar, stress, prosodic

\section{Introduction}

Each person who has the ability of speech carries lots of words in his/her mind and the man can communicate with the help of these words. As dictionaries are full of words the brain of a man that was created by God is rich in words as well as with the meanings of the words. The meanings of the words that a man uses in his/her speech is related with the man's former knowledge that exist is his/her brain. If we want to express it in a literary way a man can be called a walking dictionary created by God, but this dictionary can walk, speak, and has consciousness. We even ourselves do not know how many words there are in our minds, and how many meanings each word has. This happens in the result of the mysterious process that goes on in the brain of a human being. And this is the problem that has been under discussion for ages. We have also been interested in the investigation the meanings of the words. Do all words that are in human's brain have meanings? And how are the meanings of these words studied? These are the questions that have been scratching my brain for a long time.

\section{Scope of the Study}

Traditionally semantic is defined to study the meanings of words. This is the definition that the linguists often use. It means that if we want to study the meanings of words firstly we need to study its semantic meaning.

The words that we use are considered to be the part of a person's linguistic knowledge and the part of a grammar as well. Depending on different kinds of situation words can give various meanings.

Look at the English term "mean" inside some contexts and observe its various usage inside them.

(1) Mary means well

The sentence means that Mary doesn't harm anyone, and she has a good intension towards everyone. Actually, the intension of the speaker is not clear in the sentence. Other example using the word "mean" inside other context:

(2) That red flag means danger.

Using this example everyone understands the danger of the red flag. Hearing this sentence everybody becomes aware that there is some danger for instance, a crevasse on a snow hillside or the imminent use of explosives in a nearby quarry. Other example:

(3) Smoke means fire.

As we see the word smoke means warning. Each of these sentences means warning but in different concepts. Look at the meanings of the warning in these examples. As you see the word "mean" is used in each of the sentences, but they introduce different linguistic meanings. We can explain the differences like this: (3) smoke- 
is a natural sign of fire, it is casually connected to the object that it signifies. It expresses fire and fire was created culturally. (2) red flag - is a conventional, or traditional sign of danger; it is a culturally established sign. The distinctions between intentional and non-intentional concepts express natural and normal signs, on the other hand they organize the main part of the theoretical investigation of the meaning (Lyons, 2002). Veysalli writes about the meanings of the words: "Each word has its own meaning. Meaning can change depending on the situation. If we do not understand the meaning of the words, we may express it another way. Because it is sometimes difficult to catch the meanings of some words without any explanation. He (Veysalli) points out the importance of the context for catching the meanings of the words. Wittgenstein wrote "usually the usages of the words make us think but not the meanings of the words. (Veysalli, 2013)

Language-speech opposition is used depending on their explanation both orally and written form. It is necessary to stress that for expressing the meanings of words more exactly our suppositions about the world knowledge have also a great role. We can say that generally natural-language speeches are expressed in a larger context of the meanings. We can feel this difference clearly if we take them from the context. As we mentioned above semantics is just helpful for distinguishing these meanings. For example:

"Soporific" means "tending to produce sleep". The main aim is not to draw your attention to the meaning of the sentence, but to the English word soporific. Here appears such a kind of opposition that the meanings which the people want to express are observed with the difference of the meanings which the words express. It is important to state that the sentence expresses the intentional meaning, though the word expresses non-intentional meaning. The meanings of the words can be distinguished depending on the situation that is used. Every natural language has its own word stock, and each word has its form and meaning. Lyons writes: "All natural languages have their own words and each word has its form and meaning. The meaning of the sentence is defined by the meanings of words that organize the sentence." (Lyons, 2002). Not any of these suppositions are argumentative. Each of them sounds correct. The meaning of the sentence is clarified not only by the meanings of the words that organize it but also the grammatical structure of the sentence has a great importance in it. It is possible that the two sentences that are made up by the same words may express various meanings according to the grammar rules. Let us look at such kinds of examples:

It is snowing now.

Is it snowing now?

The first sentence is a declarative sentence; the second one is an interrogative sentence. The grammatical difference is shown in the corresponding grammatical structure they express.

Other examples:

John admires Mary.

Mary admires John.

Though both of these sentences are declarative ones, there are also some differences in their form and meaning. Lyons call these kinds of differences as word-meaning and sentence-meaning (Lyons, 2002).

Veysalli stresses the role of prosodic elements for distinguishing the form and meaning inside the sentence. He especially specifies the role of the intonation among the prosodic elements. He writes about the intonation: "Intonation is a phonological means that has corresponding succession of the tone, tember, and strong voices of the speaker's pronunciation. Word combinations are used as a complete thought, and the listener receives it as complete information by the help of the intonation words." (Veysalli, 2008).

It means that like semantics and grammar, intonation has also its role for differentiating the meaning of the words as well as the sentence. Let us look at the following example:

/hi:" iz 'not draivin to 'kla:s tə'moro-//

"He is not driving to class tomorrow".

1) If we put the stress on the word "class", then we give the information about his plans for tomorrow, what he is going to do tomorrow.

2) If we put the stress on the word "driving", then we draw out attention to the vehicle that he will drive.

3) If we put the stress on the word "he", then we draw the attention to the doer of the action.

As we see, putting the stress on different kinds of words the meaning can change. Lyons states not only the prosodic means in speech and writing are important but metalinguistic functions need attention too (Lyons, 2002). 


\section{Example:}

John said it was raining.

This sentence can be pronounced in different ways. If we put the stress on the words said and it, in this case the prosodic passage can be distinguished between writing and speech.

John said [that] it was raining.

and

John said, "It was raining".

It is necessary to stress that for showing the structural relations in writing and for the correct meaning of the sentence the roles of punctuation marks ant deniable. Let us observe the differences that the punctuation marks are formed between the ordinary-language metalinguistic sentences and speech sentences:

I cannot stand, Sebastian!

I cannot stand "Sebastian".

The difference is seen obviously. In the first sentence the speaker speaks to the man whose name is Sebastian; in the second sentence the speaker states that he/she dislikes the name Sebastian as a notion. The investigations show that there are some theories for defining the meanings of the words. Let us form such a kind of listing:

a) the referential (or denotational) theory ("the meaning of an expression is what it refers to (or denotes), or stands for"; e.g., "horse" means either the general class of dogs or the essential property which they all share);

b) the ideational, or metalistic theory ("the meaning of an expression is the idea, or concept, associated with it in the mind of anyone who knows and understands the expression");

c) the behaviourist theory ("the meaning of an expression is either the stimulus that evokes it or the response that it evokes, or a combination of both, on particular occasions or utterance");

d) the meaning-is-use thoery ("the meaning of an expression is determined by, if not identical with, its use in the language")

e) the verificationist theory ("the meaning of an expression, if it has one, is determined by the verifiability of teh sentences, or propositions, containingit")

f) the truth-conditional theory ("the meaning of an expression is its contribution to the truth-conditions of the sentences containing it") (Lyons, 2002)

Each of these theories has its role in forming the meaning of words in the ordinary language usage. But of course, not all words have the same kind of meaning as others. Some words have more meanings; some have less, some have none.

\section{Full and Empty Words}

While investigating the meanings of words we found out that the word forms in the English language like some other languages can be divided into two classes. The first class is the words that are called full words (or meaningful words) such as man, came, green, badly etc. The other class words is called empty words (or form words; or meaningless words) such as the, of, and, to, if and others. As we stated above the "empty word forms" can be named as function word, grammatical word, form word by some linguists. Henry Sweet, the nineteenth-centry English grammarian drew the above mentioned distinction between "full words" and "form words". But there are also some terms that can replace the terms given by H.Sweet. For instance, the Azerbaijani grammarian Musayev uses the terms as notional words and functional words $(4$, p. 2). Though the grammarians, or the linguists use different kinds of terms for meaningful and meaningless words both of these classes of words serve for the same purposes. Full words have their full meanings, and it is only full words that seem to have the kind of meaning that we would expect to find in a dictionary. The form words belong rather to the grammar and have only grammatical meanings. They don't have meanings when they are taken from the sentence. They have meanings only in relation to other words and even sometimes to the whole sentence. Let us compare:

For instance, Girls like to sow.

In this sentence the words girls, like, sow are meaningful words, that is why we can replace them by other words for example, Boys like to play. In both of these sentences to cannot be replaced by anything. Only inside the sentence it is wholly predictable, and has no meaning at all (Lyons, 2002) The same distinction was drawn centuries ago in the Chinese grammatical tradition; at the end of the nineteenthcentury by the English grammarian Henry Sweet; in the 1950s by the American linguist C. C. Fries (1952); by the Azerbaijani grammatist O. I. 
Musayev (1929), etc. Chomiski also supported these distinction in his generative grammar (Margaret, 2011). He (Chomski) compared the distinctions of words forms between open-class and close class (Lyons, 2002). This theory las also been keeping its essence for centuries.

In English the noun, the pronoun, the verb, the adverb, the adjective etc. are considered to be full words. The prepositions, the articles (the definite and the indefinite ones), the conjuctions and others can be given as examples to the empty words.

These terms mean that both of these two word forms differ from each other according to their semantic and grammatical meanings. The empty words are not considered to be independent terms or categories by logicians i.e., they are considered to be syncategorematic. They have forms whose meaning and logical function derives from the way in which they combine with (syn-) the independently defined major categories. Musayev states that the categorical meaning is a part of a grammatical meaning (Musayev, Hajiyev, \& Huseynov, 2009). Lyons also writes about it: "the categorical meaning is that part of the meaning of lexemes (and other expressions) which derives from their being members of one category rather than another (nouns rather than verbs, verbs rather than adjectives, and so on" (Lyons, 2002).

As we stated above each distinction between full words and empty words serves its own purpose. It shouldn't be forgotten that while fullfilling their purposes in sentences they follow the rules of grammar. As the linguists state traditionally grammar is a system of rules. Musayev writes: "There do not exist such a language without grammar. The lexics does not exist without grammar. The main function - the communicative function of a language is fullfilled only by the help of grammar. The language becomes the means of communication and serves the people." (Musayev, Hajiyev, \& Huseynov, 2009). Lyons wrote: "The grammar of a language is a system of rules which determines how words are put together to form (grammatical well-formed) phrases, how phrases are put together to form (grammatically well-formed) clauses, and how clauses are put together to form (grammatically well-formed) sentences" (Lyons, 2002). Words, phrases and clauses which break the rules of grammar are traditionally described as ungrammatical sentences (or ill-formed combinations) (Lyons, 2002). The grammatical meaning is observed in the grammatical structure of the language. We can say that from the grammatical point of view empty words play the same role in non-inflecting, or lowly inflecting languages as prefixes, suffixes, etc. do in highly inflecting langauges. For example, a prepositional phrase to John. In English when it is used in indirect-object position after the verb "give" it can be matched semantically and grammatically. In many highly inflectional languages such as Latin or Russian with what is traditionally referred to as the dativ (or allative) form of the noun. We can say the same words about the definite article "the". Most languages in the world do not have a separate word-form which can be identified grammatically and semantically with the English definite article (6, p. 33). It is necessary to state that the word is not a clearly defined linguistic unit. To some degree some consider it to be conventional, as defined in terms of the spaces in the written text. It is not the term that fulls the spaces in writing. It is a notion that has a meaning. One signal that draws attention in the langauge is stress. One word seems to allow one stress. For example, blàckbird (qara quş) as a single word, but blàck bírd (qara; quş) as two. Other compund words from this kind: shóeblack (ayaqqabı qarası) and shóe blàck (ayaqqabı; qara); shóehorn (dabançəkən) and shóe hórn (ayaqqabı; daban); shóepolish (ayaqqabı rəngi) and shóe pólish (ayaqqabı; rəng) and others.

Bloomfiled suggests that words can be considered to be the minimum free units (Bloomfield, 1933).

It means that words can be used in isolation as the smallest unit. But of course, it depends on what is meant using the word isolated or separated. The words such as the, is, in, and, etc. are not used separately. We use them together with other full words. Bloomfield also suggested that it is necessary to look for a smaller element than the word, a unit of meaning - the morpheme. For example, -berry in blackberry, or $-y$ in Johnny etc. Some linguists drew attention to the mophemes in wordslikeloved. In this word we can identify the morphemes love- and $-d$. In this case we had better mention the term lexeme. As lexeme is a technical term for the word that is often used by linguists. In dictionaries the words are compiled under the lexeme headings i.e., there are not such headings in dictionaries for the words love and loved. The main word is love and we should look for the word under this heading. It means that we investigate the meaning of a word separately and the independent elements i.e., plural form, or the past simple tense forms need to be investigated separately as well. It is possible to define the meanings of words without dividing them into parts. But it is possible to face some problems while catching the meanings of the elements. There are words that may have unclear meanings when we divide them into elements. For example, Bloomfield drew attention to the word cranberry (mərcanı, quşüzümü). He stated that the element cran- in this word doesn't have independent meaning, and we cannot see it in other words. Then he investigated other words such as strawberry (çiyələk) and gooseberry (motmutu). He stated that these words do not have any relation with the words straw and goose. But there are also some confusing points e.g., the word black- doesn't have any relation in 
the word blackberry though black- keeps its meaning in the words blackbird and blackboard. Then the words greenfinch, bullfinchandchaffinch also create an interesting trio. These three words express the meaning of finch Green- in the word greenfinch defines its colour; bull-in the word bullfinch doesn't have any relation to this word; chaf- in the word chaffinch hardly has any meaning. In English some words are phonaesthetic as only one part of these kinds of words can give information about the meaning. For example, the words beginning with $s l$ - mostly express the meaning of "slippery". Such as slide, slip, slither, slush, sluice, sludge and so on.

Some words beginning with $s l$ - have the meaning of pejorative: slattern, slut, sly (hiyləgər), slovenly and others. Some words beginning with sk- express the surfaces or superficiality: skate, skimp, skim, skin and others. We can also look in the meanings of the words in the dictionaries beginning with $s n$-, str-, sw-, $t w$ - and so on. We are sure that we will observe the same similar forms. Now let us look at the list of the words ending in -ump. Almost all express some kind of roundish mass, plump, chump, rump, kump, lump, bump, stump and we can also add the words dump and mumps to this list. Naturally, not all words in the English language do not express their meanings following such phonological features. There is not such a succession in semantic combinations inside the words that we can know. So, this investigation leads us to the point of expressing the meanings of the same words with different elements (Bloomfield, 1933). Ullmann made this distiction between transparent words and opaque words (Ullman, 1962). Transparent words are clearly defined. Such as we can determine their meanings from the meaning of their parts. Opaque words are those whose meaning can not be determined from the meaning of their parts.For example,

The words like chopper and doorman refer to transparent words; the words like axe and porterrefer to opaque words. If we pay attention, we can observe that it is possible to form the meaning by connecting some words. The phraseological units, idioms, etc. can be given examples to such kind of words. Let us look through some idioms. As we know the meanings of idioms can not be predicted from the meanings of the words forming them. For example,

Fly off the hands (to get angry), spill the beans (to reveal a secret), red herring (false story) and others. As we see the meanings of the idioms often differ from the meanings of the words forming them. We need to be very attentive while using the idioms in the sentence. Though idioms are considered to be the single units, but semantically they are not single grammatical units. For example, for forming the past indefinite tense form of the idiom "fly of the handle" we add the suffix -ed not to the last word as a single grammatical unit its past tense form is flew of the handle (not fly of the handled).

While investigating we found out that sometimes semantic division overrides word division. For example, let us use the words heavy smoker and good singer in the sentences.

(1) My brother is a heavy smoker;

(2) This woman is a good singer.

Semantically in the expression heavy+smoker the meaning is not "a smoker who is heavy" (ağır olan siqaret çəkən), but it describes the one who smokes heavily. Similarly in the expression good +singer the meaning is not "a singer who is good", but the singer who sings well. If we try to keep the parallelism and try to make changes, in this case the meaning will be like this heavy smoke and good sing. These will lead to the grammatical ambiguity (Bloomfield, 1933).

\section{Conclusion}

A healthy born man hears the word as soon as he/she opens his/her eyes to the real world. Gradually he/she learns to use the words in his/her speech and step by step he/she is able to speak. The process has been going on like this for ages. So the meanings of words, the formation of words, the division of words, the variation of words, etc. have always been considered to be the actual investigating sources. The meaning of full word-forms has both lexical and grammatical meanings. Unlike them the empty word-forms do not have any lexical meaning at all. That is why they are considered to be semantically empty. Moreover, full word-forms are forms of the major parts of speech, such as nouns, verbs, adjectives, etc. In contrast, empty word-forms in English refer to smaller form-classes, such as articles, conjunctions, prepositions, etc. Traditionally they are defined by their syntactic functions, rather than semantically.

\section{References}

Bloomfield, L. (1933). Language. New York: Holt; and (1935) London: Allen and Unwin.

Lyons, J. (2002). Linguistic Semantics. Cambridge: Cambridge University Press. 
Margaret, T.(2011). Fifty Key Thinkers on Language and Linguistics. London and New York: Routledge Taylor and Francis Group.

Musayev, O. I., Hajiyev, E. I., \& Huseynov, A. R. (2009). A Practical Grammar of Contemporary English. Baku: Qismet.

Palmer, F. R. (1981). Semantics. London, New York, New Rochelle, Melbourne, Sydney: Cambridge University Press.

Ullman, S. (1962). Semantics: an introduction to the study of meaning. Oxford: Basil Blackwell.

Veysalli, F. Y. (2008). The bases of Structural linguistics II. Studia Philologica II. Baku: Mutarcim.

Veysalli, F. Y. (2013). The bases of Linguistics. Studia Philologica VI. Baku: Mutarjim.

\section{Copyrights}

Copyright for this article is retained by the author(s), with first publication rights granted to the journal.

This is an open-access article distributed under the terms and conditions of the Creative Commons Attribution license (http://creativecommons.org/licenses/by/3.0/). 